\section{Evolution and Entropy}

For an essay on "Evolution and Entropy" Mr. E. H. Betts has been awarded the Langhorne Orchard Prize of the Victoria Institute. The main thesis propounded is, that since in the author's opinion 'evolution' is contradicted by the law of entropy and the latter is beyond all question true, then 'evolution' is false or presumably has not taken place. The argument is put forward in a plausible manner and the essay makes interesting reading. What the author understands or means by 'evolution' is not at all clear, and sometimes he uses the word in the sense of change from simple to complex, sometimes it appears to have a moral, ethical or even religious meaning, and sometimes it is a striving towards perfection, whatever that may be. It is a relatively simple matter to endorse any of these points of view by quotations from some author or other, and then reduce to an absurdity or contradiction deductions that can be made from such quotations. Stress is laid on the difficulty of giving a logical statement of the derivation of living from non-living matter, but it seems equally clear that the law of entropy postulates the existence of matter capable of physical measurement but throws no light upon the origin of the matter itself. The ordinary mind has difficulty in imagining, let alone comprehending, that originally there was nothing, and then suddenly there was something; or the other alternative, that matter has always existed.

Mr. Betts suggests that in Nature and history the direction of progress is from complex to simple; presumably the organization of our society to-day is more simple than that of the ancient Britons. No biologist familiar with fossil faunas and floras would agree that this is true of the geological records of animals and plants. But perhaps all is well, for the author himself uses the sentence "Evolution itself thus rapidly evolved", and so employs a word which is extremely convenient to express the general idea that, in non-living as in living things, with the passage of time, a change or progression, so long as this is not intended to mean a movement limited to one direction, is, in fact, observable.

\section{Differential Fertility in Canada}

CANADA with its many wide spaces and farm lands has tended in the last few years to become more industrialized. It contains a large population of emigrants or the immediate descendants of emigrants from parts of Europe where tradition has influenced the reproductive tendencies of the people. For the future of Canada, which is under-populated, it is of some concern to understand the fertility of different groups of the population in order to supply information for policy-framing. Enid Charles (Canad. $J$. Econ. and Pol. Sci., 9, 175; 1943) presents an analysis of the differential fertility as seen in the 1931 census. The highest fertility is seen in Quebec and New Brunswick, the lowest in Ontario and British Columbia. There is high fertility among farmers, fishermen and food operatives, and low fertility among textile operatives, loggers, personal service workers, salesmen, owners and managers of manufacturing concerns. The late marriage of office workers and loggers could account for their low replacement birth-rate, while the small size of families of owners and managers accounts for the low fertility of these classes. Provincial differences contribute equally with occupational differences to fertility differences, while origin and religion of the individual are contributing causes. It is important to note that British Columbia, with a comparatively small population, is in reality urban in type-it has a high plane of living, a large majority of Protestants. The fertility is low. In a developing country like Canada, it should be possible to frame the policy and development of the country to encurage higher birth-rates in those sections of the community which are reduced, but it would seem that the Canadian population may tend to repeat the faults of several European countries unless a check is made by constructional legislation.

\section{Nature of the Viruses}

Prof. B. F. Osorio Tafall, National School of Biological Sciences, I. P. N., Mexico, has an article with the title "Naturaleza De Los Virus", in Ciencia of August 1943, which gives a very useful survey of the work done on viruses. While there is nothing added to our knowledge of the subject by this contribution, it provides an excellent historical review. and as it is written in a popular form, it will prove acceptable to many readers. Among the methods of studying viruses are ultra filters, colour tests (used to investigate psittacosis), photomicrography by ultra-violet light, the electron microscope, etc. New laboratory methods for diagnosing certain diseases caused by a virus which attacks both man and animals have been developed recently. Thus, Hertz described in 1942 how the allantois of the embryo of a chicken, when inoculated with the virus $A$ and $B$ of influenza, possesses the power of agglutinating the hæmatin, and this provides a simple test for detecting the virus of influenza in the throat and for determining the antibodies existing in the serum of the patient. The subject will be continued in a later issue of Ciencia.

\section{The Colombian Hypericum}

An article under the title "Algunos Chites Nuevos Colombianos" appearing in Ciencia of August 1943 (published in Mexico) deals with the Colombian chite, a plant belonging to the genus Hypericum. This genus comprises about three hundred known species which are distributed in the subtropical regions, being scarce in the temperate zones. Colombia has many forms of the plant and up to the present twenty-five speries have been found in the country. The author 'of the article, Jose Cuatrecasas, Escuela Superior de Agricultura Tropical, Cali, Colombia, acknowledges his indebtedness to Dr. Prittier, through whose kindness he has been enabled to study $H$. caracasanum. As a result of his investigations a number of previous identifications have been altered, and changes made regarding certain species and new varieties. Short descriptions are given of $H$. ruscoides, $H$. magniflorum, $H$. stenoclados, H. tamanum and $H$. lancioides.

\section{Earthquakes Registered in New Zealand and Spain}

DURING November 1943, seven strong earthquakes were registered by the seismographs at the New Zealand observatories. These were on November 2, 4, 6 (two), 13, 26 and 28. The shock of November 26, with an epicentral distance from. Wellington of about $83^{\circ}$, had a focal depth estimated between $130 \mathrm{~km}$. and $140 \mathrm{~km}$. In addition, nineteen earthquakes were felt in some part of New Zealand. The strongest three of these had intensity VI and were felt (1) on November 5 from Greymouth to Arthur's Pass, (2) on 